\title{
The relationship between learning outcomes and motivation for learning to write using indonesian against student management
}

\author{
Zulaika Zulaika ${ }^{1}$, Happy Fitria ${ }^{2}$, Syaiful Eddy ${ }^{2}$ \\ ${ }^{1}$ Sekolah Dasar Negeri 2 Setia Jaya, Indonesia \\ ${ }^{2}$ Universitas PGRI Palembang, Indonesia
}

\begin{tabular}{l} 
Article Info \\
\hline Article history: \\
Received Jul $10^{\text {th }}, 2021$ \\
Revised Aug $18^{\text {th }}, 2021$ \\
Accepted Aug $30^{\text {th }}, 2021$ \\
\hline
\end{tabular}

\section{Keyword:}

Learning outcomes

Learning motivation

Student management.

\begin{abstract}
This study aims to analyze and describe: 1) the relationship between learning outcomes and student management, 2) the relationship between the motivation to learn to write in Indonesian and student management, 3) the relationship between learning outcomes and motivation to learn to write using Indonesian language against student management. The results of the study stated: 1) there is a relationship between Learning Outcomes and Student Management; 2) there is a relationship between the Motivation of Learning to Write Using Indonesian and Student Management; and 3) there is a relationship between Learning Outcomes and Learning Motivation on Student Management at Sekolah Dasar Negeri Kecamatan Jirak Jaya.
\end{abstract}

(C) 2021 The Authors. Published by IICET.

This is an open access article under the CC BY-NC-SA license

(https://creativecommons.org/licenses/by-nc-sa/4.0

\section{Corresponding Author:}

Zulaika, Z.,

Sekolah Dasar Negeri 2 Setia Jaya, Indonesia

Email: zula.ika13@yahoo.com

\section{Introduction}

Motivation is a desire from oneself or encouragement from outside parties that is owned by someone in doing work optimally in achieving work goals [1]. In line with this opinion, Gleitman (in Shah, 2013) motivation is one of the psychological factors that can affect student achievement. Motivation is a psychological factor that can affect student learning abilities. Motivation applied to Indonesian language learning becomes a good initial process before material is taught to students so that they have good language skills along with improving the quality of education, which includes aspects of writing, speaking, listening and listening skills. In line with the opinion of [2] that in principle, motivation is an impetus that exists in a person both because of his own awareness and because of an external urge to do something in the hope that the desired goal can be achieved. The good level of performance of a teacher as an educator in schools is the reason this research was conducted, as part of participating in improving the quality of education.

Based on observations on pre-classroom research activities for grade 1 students when carrying out learning activities at SD Negeri 1 Jirak, SD Negeri 2 Setia Jaya, and SD Negeri Sungai Menang, the teacher informed that in grade 1 there were several students whose writing skills were low. . The teacher argues that this may occur because the teacher has not been able to apply the right method to improve students 'writing skills and the students' lack of writing skills is due to the lack of motivation of students in writing.

The success in implementing educational institutions will be largely determined by the existing resources of the school. Therefore, the use of existing resources in schools is very important in determining the success 
of the implementation of education itself. In line with [3] that the measure of the quality of a nation can be seen from the extent to which the success of the implementation of education takes place in a country. The higher the level of community education in a nation, the higher the quality of the people of that nation. However, the reality of the Indonesian education system has yet to show the quality and success it hopes for. National education has not been able to create superior human resources, both in terms of intellectuality, morality, spirituality, professionalism and the ability of national competitiveness or competition. And in reality, education in Indonesia is difficult to make significant progress, even in a global scale, our quality is far from that of neighboring countries.

In line with the opinion of [4], the goal of a state is to educate the nation's life which should be the axis of development of national welfare and culture. What we feel now is that there is a lag in the quality of education. The low quality of education hinders the provision of human resources with expertise and skills to fulfill national development in various fields.

Student management is a process of managing all matters relating to students in a school starting from planning, student admission to coaching carried out while students are in school, until students complete their education at school through the creation of a learning atmosphere that is conducive to the ongoing process of teaching and learning or learning effectively. (Mulyasa, 2015). With the existence of school management it is expected to be able to organize various activities in the student sector so that learning activities at school can run smoothly, orderly and regularly, and achieve educational goals.

Based on the interviews of the author and teacher during pre-research activities at SD Negeri 1 Jirak, SD Negeri 2 Setia Jaya, and SD Negeri Sungai Menang as research locations, the researchers found several findings including: (1) in terms of student planning, not applying student management with good, proven by not applying standardization of the number of students in the class, so that learning outcomes in the classroom cannot be maximized; (2) in admitting new students, not implementing student management properly, it is evident in the admission of new students that schools do not determine certain qualifications for new student admissions, thus affecting the standardization of the number of classes; (3) in terms of the learning process, it does not apply student management properly, it is proven in fostering discipline and student participation in the learning process, there are still students whose participation / interest in learning is lacking, so that it affects educational outcomes.

Based on the above background, the researcher will examine the problem by conducting a study entitled "The Relationship of Learning Outcomes and Motivation for Learning to Write Using Indonesian Language Against Student Management at the State Elementary Schools of Jirak Jaya".

The objectives of this study are as follows: 1) To analyze and describe the relationship between Learning Outcomes and Student Management at SD Negeri Jirak Jaya , 2) To analyze and describe the relationship between the Motivation to Learn Writing Using Indonesian and Student Management at SD Negeri Jirak Jaya , 3) To analyze and describe the relationship between Learning Outcomes and Motivation to Learn to Write Using Indonesian Against Student Management at SD Negeri Jirak Jaya..

\section{Method}

This study uses a quantitative descriptively by using double correlation ( multiple correlation ), which is a number that indicates the direction and strength of the relationship between two variables independent together with one or more variable dependent . [5] states that the quantitative approach is the approach used by researchers in research by measuring variable indicators, so that an overview and conclusions of the research problem can be obtained.

The population in this study were all SD Negeri Jirak Jaya District, especially students in grade 1, totaling 17 State SDs consisting of 2 State SDs with A Accreditation, 12 State SDs with B Accreditation, and 12 State SDs with C Accreditation. as many as 3 State SD.

The total sample taken was 74 students, especially students in grade 1 of 3 state elementary schools with accreditation A, B and C. Where SD Negeri 1 Jirak with a total of 42 students, consisting of 22 male students and 20 female students; SD Negeri 2 Setia Jaya with a total of 24 students consisting of 11 male students and 13 female students; and SD Negeri Sungai Menang with 8 students, consisting of 4 male students and 4 female students . Data were collected using a Likert scale model questionnaire. The data analysis technique used 1) descriptive quantitative analysis technique; and 2) multiple regression. 


\section{Results and Discussions}

\section{The Relationship of Learning Outcomes on Student Management}

Results of the study showed that the results of Study (X1) of the Management of Students (Y) after analysis of data obtained by value $t_{\text {arithmetic }}(18.546)>t$ table $(1.99)$ at the significant level of $5 \%$ and a probability value (p) of $0.000<0,05$. From these results it can be concluded that there is a significant relationship between Learning Outcomes (X1) and Student Management (Y) in SD Negeri Jirak Jaya District . From this statement it can be said that $\mathrm{Ho}$ is rejected and $\mathrm{Ha}$ is accepted. In addition, it also explains the percentage of the relationship between Learning Outcomes (X1) and Student Management (Y) which is called the coefficient of determination which is the result of squaring R.From the table above, it is obtained the coefficient of determination (Adjust $R$ Square) of 0.825 which implies that the relationship Learning Outcomes (X1) on Student Management $(\mathrm{Y})$ amounted to $82.5 \%$; while the remaining $17.5 \%$ is influenced by other variables not examined in this study.

Learning outcomes are changes that occur in students, both concerning cognitive, affective and psychomotor aspects as a result of learning activities. In simple terms, what is meant by student learning outcomes is the ability the child gets after going through learning activities. Because learning itself is a process of someone trying to obtain a relatively permanent form of behavior change [6] Learning outcomes are changes or new abilities obtained by students after learning, because learning is basically how a person's behavior changes as a result of experience [7]

\section{The Relationship between Learning Motivation and Student Management}

Results of the study showed that motivation to learn (X2) on the Management of Students (Y) after analysis of data obtained by value $t_{\text {arithmetic }}(19.540)>t_{\text {table }}(1.99)$ at the significant level of $5 \%$ and a probability value $(p)$ of $0.000<0,05$. From these results it can be concluded that there is a significant relationship between Learning Motivation (X2) and Student Management (Y) in SD Negeri Jirak Jaya District . From this statement it can be said that $\mathrm{Ho}$ is rejected and $\mathrm{Ha}$ is accepted. In addition, it also explains the percentage of the relationship between Learning Motivation (X2) and Student Management (Y) which is called the coefficient of determination which is the result of squaring R.From the table above, it is obtained the coefficient of determination (Adjust $R$ Square) of 0.839 which implies that the relationship Learning Motivation (X2) on Student Management $(\mathrm{Y})$ is $83.9 \%$; while the remaining $16.1 \%$ is influenced by other variables not examined in this study.

The term motivation means the effort that encourages someone to do something. The motive cannot be observed directly but can be interpreted in the form of behavior in the form of a desire or a generator for the emergence of a certain behavior. Motivation to learn, namely external and internal encouragement for students to make changes in behavior. Basically, learning motivation is an effort based on moving, directing and maintaining a person's behavior so that he is motivated to act to do something in terms of learning, so as to achieve certain results or goals. According to Subari [8] argues that learning motivation is something that drives behavior that demands / encourages people to fulfill certain needs. This need will lead to an impulse or motive to take certain actions, where it is believed that if the action has been done, a state of balance will be achieved and a feeling of satisfaction will arise in the individual.

\section{The Relationship between Learning Outcomes and Learning Motivation on Student Management}

The results showed that the Learning Outcomes (X1) and Learning Motivation (X2) on Student Management $(\mathrm{Y})$ after the data analysis were carried out the $F$ value calculated $(15.525)>F_{\text {table }}(3.12)$. Then the significance test obtained the value of Sig $=0.000<0.05$. Hypothesis 3 test results can be concluded that there is a significant relationship together Learning Outcomes (X1) and Learning Motivation (X2) on Student Management (Y).

In addition, it also explains the percentage of the relationship between the independent variables (Learning Outcomes and Learning Motivation) on the dependent variable (Student Management) which is called the coefficient of determination which is the result of squaring R.From the table above, the coefficient of determination (Adjust $R$ Square) is obtained . amounting to 0.870 which implies that the relationship of the independent variables (Learning Outcomes and Learning Motivation) to the dependent variable (Student Management) is $87 \%$; while the remaining $13 \%$ is influenced by other variables not examined in this study. The findings of this study are in line with the results of research by Comalasari, Harapan, and [9]entitled, "The Effect of Principal's Democratic Leadership Style, Teacher Competence and Classroom Management on Learning Quality". The results of this study indicate that: 1) there is an influence of the principal's democratic leadership style on the quality of learning, 2) there is an effect of teacher competence on the quality of learning; 3 ) there is an effect of class management on the quality of learning, and 4) there is an 
influence of the principal's democratic leadership style, teacher competence and class management on the quality of learning.

Furthermore, the results of research by [10] entitled, "The Effect of Achievement Motivation and the Reward System on Teacher Job Satisfaction". The results of this study indicate that: 1) there is an effect of achievement motivation on teacher job satisfaction at SMK Kota Prabumulih, amounting to 60.9\%. 2) there is an effect of the reward system on teacher job satisfaction at SMK Kota Prabumulih, amounting to 70.7\%. 3) there is an effect of achievement motivation and reward system on teacher job satisfaction at SMK Kota Prabumulih, amounting to $76.7 \%$.

According to [11] student management can be interpreted as an effort to regulate students, starting from these students entering school until they graduate, which is regulated directly the aspects that are related to students indirectly. Arrangements for other aspects besides students are intended to provide the best possible service to students.

According to [12] that the principles of student management are as follows: 1) Student management is seen as part of the overall school management; 2) All forms of student management activities must develop an educational mission and in order to educate students; 3) Student management activities should be endeavored to unite students who have various backgrounds and have many differences; 4) Student management activities must be viewed as an effort to regulate student tutors. because of guiding, there must be the availability of the mentored party. is the student himself; 5) Student management activities must encourage and spur student independence; and 6) What is given to students and what student management activities always strive for must be functional for the student's life both in school, especially in the future.

\section{Conclusions}

Based on the results of data analysis, it can be concluded that: 1) there is a relationship between Learning Outcomes and Student Management; 2) there is a relationship between the Motivation of Learning to Write Using Indonesian and Student Management; and 3) there is a relationship between Learning Outcomes and Learning Motivation on Student Management at the Jirak Jaya District Elementary Schools by looking at the value of $F_{\text {count }}(15.525)>F_{\text {table }}(3.12)$ and a significance value of $0.000<0.05$ which is shown by the regression line equation $\mathrm{Y}=10.678+0.797 \mathrm{X} 1+0.701 \mathrm{X} 2$. Learning Outcomes and Learning Motivation were able to influence Student Management by $87 \%$; while the remaining $13 \%$ is influenced by other variables not examined in this study.

\section{References}

Arikunto, S. (2013). Manajemen Penelitian. Jakarta: Rineka Cipta.

Badrudin. [7] Rusmono. (2014). Strategi Pembelajaran dengan Problem Based Learning Itu Perlu. Bogor: Ghalia Indonesia. (2016). Manajemen Peserta Didik. Jakarta: PT Indeks.

Comalasari, E, Harapan, E., dan Houtman. (2002). Pengaruh Gaya Kepemimpinan Demokratis Kepala Sekolah, Kompetensi Guru dan Manajemen Kelas terhadap Mutu Pembelajaran. Journal of Innovation in Teaching and Instructional Media, Vol. 1 No. 1, September 2020 Page:74-84. September 2020 Page:46-57..

Damayani, T., Arafat, Y., dan Eddy, S. (2020). Pengaruh Kepemimpinan Kepala Sekolah dan Motivasi Kerja terhadap Kinerja Guru. Journal of Innovation in Teaching and Instructional Media, Vol. 1 No. 1,

Fitria, H, Astuti, P., Fitrianti, Y. (2020). Pengaruh Kepemimpinan Kepala Sekolah dan Motivasi Kerja terhadap Kinerja Pegawai. Jurnal Pendidikan Tambusai, SSN: 2614-6754 (print) ISSN: 2614-3097(online) Halaman 3429-3438 Volume 4 Nomor 3 Tahun 2020.

Fitria, H, Marphudok, Lian, B. (2020). Pengaruh Lingkungan Kerja dan Motivasi Kerja terhadap Kinerja Guru SMA di Kecamatan Muara Padang. Jurnal Intelektualita: Keislaman, Sosial, dan Sains, Vol. 9, No. 1, Juni 2020, ISSN 2303-2952, e-ISSN 2622-8491.

Imron, A. (2017). Manajemen Peserta Didik Berbasis Sekolah. Jakarta: Bumi Aksara.

Masilawati, Harapan,. dan Wardiah, D. (2020:1989-1998). Pengaruh Motivasi Berprestasi dan Sistem Penghargaan terhadap Kepuasan Kerja Guru. Jurnal Pendidikan Tambusai. SSN: 2614-6754 (print) ISSN: 2614-3097 (online) Halaman 1989-1998 Volume 4 Nomor 3 Tahun 2020.

Suparman, S. (2010). Gaya Mengajar yang Menyenangkan Siswa. Yogyakarta: Pinus Book Publisher.

Utamy, R, Ahmad, S., Eddy, S. (2020). Implementasi Manajemen Sumber Daya Manusia. Journal of Education Research, 1(3), 2020, Pages 226-236

Susanto, A. (2015). Teori Belajar dan Pembelajaran di Sekolah Dasar. Jakarta: Bumi Aksara. 